\title{
Studies on Propagation of Ezo Abalone, Haliotis discus hannai INo-I
}

\author{
Analysis of the Relationship between Transplantation and Catch \\ in Funka Bay Coast
}

\author{
Katsuo SAITo*: \\ (Received January 9, 1979)
}

\begin{abstract}
Ezo abalones did not originally inhabit Funka Bay, but now live widely in this area as a result of transplantation. To six places within the Bay are transplanted 85,450 to $1,636,727$ seeds of abalone to give catches in these places ranging from zero to $148,919 \mathrm{~kg}$. During the years of 1971 to 1976 , abalone samples were collected at six stations in the bay (inhabited by Ezo abalones) and shell length, age, and growth rate of these samples were examined. The dependence of total weight on shell length as well as the relationship among various measurements of abalone shell were analyzed. Furthermore, the effects of abundance of algae and water temperature on the efficiency of transplantation were investigated. Most of the samples had shell lengths of 7 to $9 \mathrm{~cm}$. Oshamanbe, Toyoura and Usu often produced abalones having shell lengths larger than $11 \mathrm{~cm}$. Four to six year old shells constituted the main age group. Only a few samples were older than 10 years. Toyoura was found to provide the fastest growth rate: $9.6 \mathrm{~cm}$ in four years, $12 \mathrm{~cm}$ in six years, $13 \mathrm{~cm}$ in eight years and $14 \mathrm{~cm}$ in ten years. Abalones feed on some kinds of algae. Undaria pinnatifida $f$. distans, Desmarestia viridis and Ulva pertusa are available to depths as deep as $10 \mathrm{~m}$ in most of the places studied. However no useful algae live beyond $5 \mathrm{~m}$ depth in Okushiri. Water temperature in the shallow areas within the Bay does not drop to $3^{\circ} \mathrm{C}$ even in winter, namely between January and March. We cannot find abalone in places where the water temperature is below $3^{\circ} \mathrm{C}$ winter. The survival rate of transplanted abalones within the Bay was estimated to be 25 to $30 \%$ after two years of transplantation based on the ratio of transplantation to catch as well as on the proportion of the first generation abalones found in the sample.
\end{abstract}

The northern inhabit limit of Ezo abalone along the Pacific coast of Hokkaido is Muinoshima, Toi, near Hakodate, according to Yamaguchi. ${ }^{2 \prime}$ Handa $^{2)}$ studied topography of the sea bottom and distribution of algae in the northern part of Funka Bay between Usu and Shizukari and found this area suitable for rearing Ezo abalone. Based on his suggestion, seed abalones were transplanted from Mashike and Teuri on the coast of the Sea of Japan to Usu, Abuta and Toyoura between 1929 and $1935^{3,4 !}$. Kinoshita ${ }^{5)}$ observed that the abalones grew faster in these places than on the coast of the Sea of Japan. Kawai et al. ${ }^{6,7}$ also succeeded in transplanting abalones to Daikokushima, Muroran. All these studies prompted transplantation of abalones to Funka Bay on the commercial scale. With the development of transplantation business, Okushiri Island was chosen in 1954 as the only seed supply area in view of its abundant resouce, slow growth and the situation that the sea around the island was legally protected from abalone catchers.

The coast along Funka Bay had initially no natural abalone abundance but grew to an abalone fishing area as the result of transplantation. For this reason this area provides a model case for future propagation policies. This article describes the relation between transplantation and catch and the ecology of stocked abalone at six places along the Bay.

\section{Materials and Methods}

Samples were collected at Shikabe at the mouth of Funka Bay, and at Oshamanbe, Toyoura, Abuta, Usu, and Muroran, the last five places being located at the north to east coast of the Bay. The collection times of the year were October of 1974 at Shikabe, August of 1974 at Oshamanbe, June of 1974 at Toyoura, June of 1971 at Abuta, September of 1976 at Usu, and September of 1974 at Muroran. Thus the collection period extends from 1971 to 1976 , with 1974 at its height. Samples were collected by scuba diving method. Four to eleven sampling operations were carried out at each place. Excepting those from Abuta, the Ezo

* Hokkaido Central Fisheries Experimental Station, Yoichi, Hokkaido 046, Japan (斎藤勝男：北海道立 中央水産試験埸). 


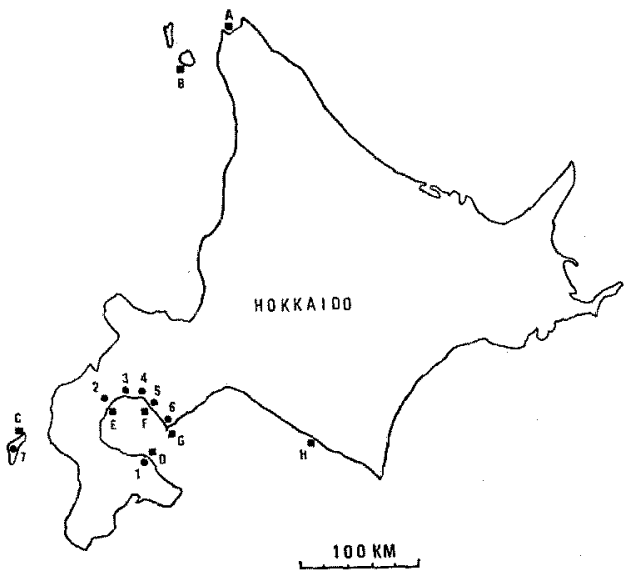

Fig. 1. Map of sampling stations (1-7) and the stations where the temperature of sea water was measured (A-H).

(1: Shikabe, 2: Oshamanbe, 3: Toyoura, 4: Abuta, 5: Usu, 6: Muroran, 7: Okushiri, A: Wakkanai, B: Senposhi, C: Okushiri, D: Shikabe, E: Oshamanbe, F: Usu, G: Muroran, H: Urakawa). abalone samples thus collected were used for measurements of shell length, shell width, shell height, total weight, the weight of soft body and age. Age was determined by counting the number of rings on the surface of shell following Hayashi" ${ }^{81}$, Sakai $^{91}$ and Tomita and Saito ${ }^{10 !}$. The second generation were distinguished from transplanted ones. The judgement of the generation of sample was made based on criterion: the presence or absence of a disturbed ring on the surface of shell, which appears at the time of transplanting and can be distinguished from the nearby rings by the difference in growth rate.

\section{Results and Discussion}

\section{Amounts of Transplantation of Seed Abalone}

Table 1 summarizes the annual change in transplanted seed abalones over a period of 25 years between 1950 and 1974. Transplantation in Shikabe started only recently: starting from 1971, 14,500 to 30,950 seeds per annum or 85,450 in total have been transplanted. In Oshamanbe, 18,750 and 21,900 seeds were transplanted in 1954

Table 1. Annual amounts of transplanted seed abalone in Funka Bay

\begin{tabular}{|c|c|c|c|c|c|c|}
\hline \multicolumn{7}{|c|}{ Station } \\
\hline Year & Shikabe & Oshamanbe & Toyoura & Abuta & Usu & Muroran \\
\hline 1950 & & & & & 18,000 & 1,680 \\
\hline '51 & & & & & 36,000 & 2,250 \\
\hline$' 52$ & & & & & & 11,250 \\
\hline '53 & & & & & 90,000 & 88,320 \\
\hline$' 54$ & & 18,750 & & & & 68,640 \\
\hline '55 & & 21,900 & & & 56,000 & 63,000 \\
\hline '56 & & & & & 60,000 & 67,500 \\
\hline 57 & & & & & 80,000 & 67,500 \\
\hline '58 & & & 53,460 & & 100,000 & 126,800 \\
\hline '59 & & & 61,618 & & 95,000 & 60,000 \\
\hline '60 & & & 73,467 & & & 60,000 \\
\hline '61 & & & 37,500 & & & 37,500 \\
\hline '62 & & & 19,500 & & & 19,500 \\
\hline '63 & & 15,000 & 33,000 & 15,000 & & 18,000 \\
\hline '64 & & 37,500 & 99,000 & 30,000 & 15,000 & 18,000 \\
\hline '65 & & 27,500 & 182,420 & 30,000 & 30,000 & 30,000 \\
\hline 66 & & 30,000 & 128,100 & 37,500 & 45,000 & 15,000 \\
\hline 67 & & 31,500 & 181,100 & 37,500 & 45,000 & 22,500 \\
\hline 68 & & 22,500 & 82,800 & 37,500 & 45,000 & 22,500 \\
\hline '69 & & 33,000 & 128,485 & 24,000 & 45,000 & 28,500 \\
\hline 70 & & 27,000 & 107,177 & 24,000 & 45,000 & 28,500 \\
\hline$' 71$ & 20,000 & 37,000 & 218,100 & 24,000 & 135,000 & 28,500 \\
\hline 72 & 14,500 & 36,250 & $7,8,000$ & & 150,000 & 28,000 \\
\hline 73 & 30.950 & 33,000 & 78,000 & & 150,000 & 28,000 \\
\hline 74 & 20,000 & 33,000 & 75,000 & & 150,000 & 52,130 \\
\hline Total & 85,450 & 403,900 & $1,636,727$ & 259,500 & $1,390,000$ & 993,570 \\
\hline
\end{tabular}


and 1955, respectively. After seven years of suspension, transplantation was resumed and a total of 403,900 seeds have been transplanted continuously from 1963 at the rate of 15,000 to 37,000 seeds per annum. Transplantation to Toyoura began in 1958 and has continued to a grand total of $1,636,727$ seeds with a maximum annual record of about 220,000 seeds and a minimum record of 19,500. This place has accepted the largest amounts of seeds among the six places studied. Usu started this business as early as 1950 and the total transplantation has reached to $1,390,000$ seeds with a maximum annual record of 150,000 seeds and a minimum record of 18,000 seeds. Muroran has continuously transplanted abalone ever since 1950, totalling 993,570 seeds until now. The maximum yearly record was 127,000 seeds and the minimum 1,700 .

\section{Amount of Catch}

Table 2 shows annual catches of abalone at the sampling stations. In Shikabe, the catch was less than $1 \mathrm{~kg}$ in 1968 . In Oshamanbe, the catch was started from 1962 yielding a total of 34.1 tons with the annual catch of 1 to 5 tons. In Toyoura, the catch has continued every year starting from 1958 with a recorded high of about 20 tons in a year. The total catch so far amounts to 148.9 tons.
Abuta has been producing 1 to 2 tons of abalone per year since 1965 . The total catch at this station so far is 10.3 tons. In Usu, 1955 was the year of start of the abalone catch. Although the catch was prohibited for two years in 1960 and 1961, a total of 71.5 tons has so far been raised including a record high of 11.5 tons per year. Muroran started the catch in 1959. After several closed seasons, anmual catch of 2 to 3 tons has continued since 1968. The total catch amounts to 22.6 toms. The record catch per year is $4,723 \mathrm{~kg}$ in 1970 .

We have briefly surveyed above the history of transplantation and the present status of catch of abalone at sampling stations. Ecological informations of transplanted Ezo abalone are discussed below in comparison with those in Okushiri Island from where the seeds came.

\section{Shell Length Distribution}

Fig. 2 summarizes abalone shell length distribution from the six sampling stations as well as Okushiri Island. In Shikabe, the modal shell length is $8 \mathrm{~cm}$ while the data distributed between 6 and $11 \mathrm{~cm}$. In Oshamanbe, the range of distribution was between 6 and 13, with the peak at 8 to $9 \mathrm{~cm}$. Toyoura abalones can be divided into two groups, the one having about $1 \mathrm{~cm}$ of length and the other having lengths between 4 and

Table 2. Annual catches of abalone in Funka Bay from 1958 to $1974(\mathrm{~kg})$

\begin{tabular}{|c|c|c|c|c|c|c|}
\hline \multicolumn{7}{|c|}{ Station } \\
\hline Year & Shikabe & Oshamanbe & Toyoura & Abuta & Usu & Muroran \\
\hline 1955 & & & & & 450 & \\
\hline$' 56$ & & & & & 638 & \\
\hline 37 & & & & & 863 & \\
\hline '58 & & & 430 & & 859 & \\
\hline$' 59$ & & & 1,226 & & 458 & 260 \\
\hline ' 60 & & & 1,416 & & & 810 \\
\hline '61 & & & 3,736 & & & 581 \\
\hline '62 & & 1,482 & 5,118 & & 55 & \\
\hline '63 & & 1,800 & 7,383 & & 2,375 & \\
\hline '64 & & 1,400 & 8,625 & & 5 & \\
\hline '65 & & 1,300 & 11,368 & 1,136 & 2,513 & 137 \\
\hline '66 & & 2,230 & 16,965 & & 4,863 & \\
\hline 67 & & 3,900 & 14,894 & 2,050 & 6,176 & 2 \\
\hline$' 68$ & & 5,000 & 16,236 & 1,697 & 7,968 & 2,459 \\
\hline 69 & & 3,000 & 19,085 & 1,675 & 7,629 & 2,323 \\
\hline '70 & & 5,000 & 19,698 & 1,312 & 11,483 & 4,723 \\
\hline 71 & & 3,000 & 8,626 & 1,460 & 7,153 & 3,419 \\
\hline${ }^{\prime} 72$ & & 3,000 & 7,152 & & 7,031 & 2,600 \\
\hline 73 & & 1,000 & 4,159 & & 4,952 & 2,359 \\
\hline 74 & & 2,000 & 2,802 & 1,000 & 5,995 & 3,000 \\
\hline Total & & 34,112 & 148,919 & 10,330 & 71,466 & 22,673 \\
\hline
\end{tabular}




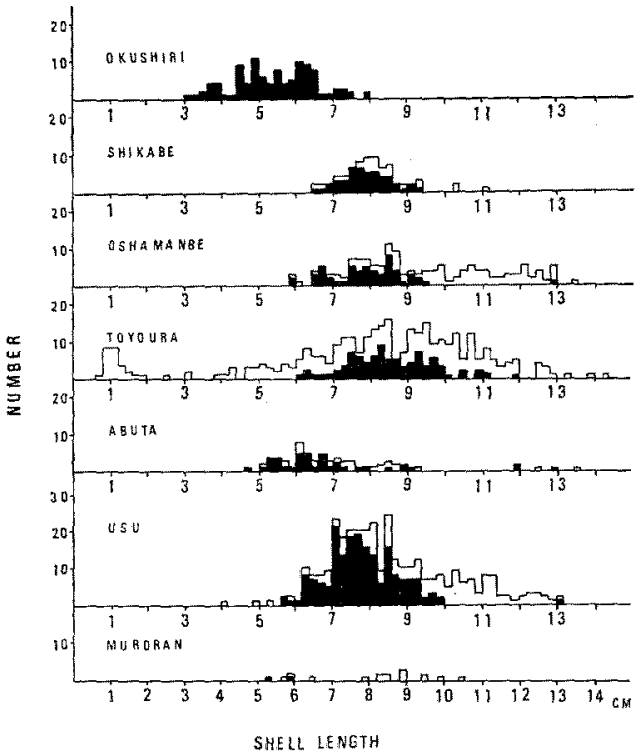

Fig. 2. Shell length distribution of abalone samples from Funka Bay area and Okushiri Island (Shadow show the transplanted abalones)

$14 \mathrm{~cm}$ with those of 6 to $12 \mathrm{~cm}$ being most abundant. In Abuta, large abalones having lengths of 12 to $13 \mathrm{~cm}$ appear in addition to a smaller group having lengths of 5 to $9 \mathrm{~cm}$. Samples from Usu have lengths ranging from 4 to $13 \mathrm{~cm}$. Distribution is concentrated on 6 to $11 \mathrm{~cm}$ range. Only a few samples have been collected in Muroran, the shell lengths of which being 5 to $10 \mathrm{~cm}$. In contrast to these sample stations, Okushiri produces abalones having lengths of 3 to $8 \mathrm{~cm}$, mainly 5 to $6 \mathrm{~cm}$.

\section{Age Distribution}

Age distribution of abalone samples from the sampling stations excluding Abuta and Okushiri are given in Fig. 3 and Table 3.

In Shikabe, the age of collected samples ranged from 2 to 7 years. More than $35 \%$ of the samples were 3 to 4 years old. Samples from Oshamanbe were 2 to 10 years old, of which $60 \%$ were 4 to

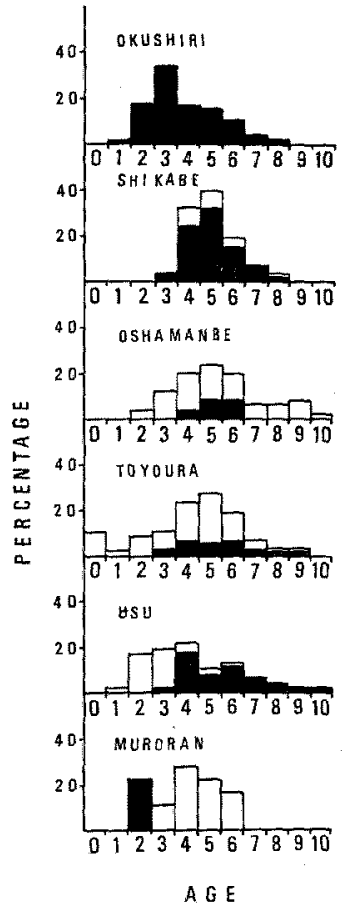

Fig. 3. Age distribution of abalone samples from Funka Bay area and Okushiri Island (Shadow show the transplanted abalones).

6 years old. In Toyoura, the age of samples ranged between 0 to 9 years old. It is to be noted that $9.9 \%$ of all sample were zero years old. Samples collected at Usu were 1 to 9 years old, of which those of 2 to 6 years old comprised $80 \%$. In Muroran, abalones of 2 to 6 years old were collected, of which the most abundant were 4 years old comprising $28 \%$ of the total.

\section{Growth}

Table 4 shows growth of abalone samples from sample stations excluding Abuta and Okushiri. The mean shell length at each age was calculated using only the individuals which were born and

Table 3. Age composition of abalone (\%)

\begin{tabular}{|c|c|c|c|c|c|c|c|c|c|c|}
\hline \multirow{2}{*}{ Station } & \multicolumn{10}{|c|}{ Age group } \\
\hline & 0 & 1 & 2 & 3 & 4 & 5 & 6 & 7 & 8 & 9 \\
\hline Okushiri & . & 1.0 & 17.5 & 34.0 & 16.5 & 15.5 & 9.7 & 3.9 & 1.9 & \\
\hline Shikabe & & & 3.2 & 35.5 & 38.7 & 12.9 & 6.5 & 3.2 & & \\
\hline Oshamanbe & & 0.7 & 2.8 & 11.9 & 18.9 & 23,1 & 18.2 & 7.0 & 7.0 & 2.8 \\
\hline Toyoura & 9.9 & 1,4 & 7.5 & 8.8 & 20.4 & 24.1 & 16.7 & 6.1 & 3.1 & 2.0 \\
\hline Usu & & 2.3 & 17.0 & 19.3 & 21.6 & 10.2 & 12.5 & 6.8 & 3.4 & 6.9 \\
\hline Muroran & & & 22.2 & 11.1 & 27.8 & 22.2 & 16.7 & & & \\
\hline
\end{tabular}


Table 4. Mean shell length of abalone at each age in Funka Bay $(\mathrm{cm})$

\begin{tabular}{lcccrrrrrrr}
\hline \hline \multirow{2}{*}{ Station } & \multicolumn{10}{c}{ Age groups } \\
\cline { 2 - 12 } & 1 & 2 & 3 & \multicolumn{1}{c}{4} & \multicolumn{1}{c}{5} & \multicolumn{1}{c}{6} & \multicolumn{1}{c}{7} & \multicolumn{1}{c}{8} & \multicolumn{1}{c}{9} & 10 \\
\hline Okushiri & 2.08 & 3.31 & 4.35 & 5.18 & 5.88 & 6.39 & 6.93 & 7.18 & 7.57 \\
Shikabe & 2.56 & 4.03 & 5.59 & 6.83 & 7.75 & 8.34 & 8.68 & 9.06 & 9.37 & \\
Oshamanbe & 2.53 & 4.28 & 6.57 & 8.14 & 9.26 & 9.98 & 10.69 & 11.20 & 11.45 & 11.60 \\
Toyoura & 2.39 & 4.27 & 6.27 & 9.63 & 10.98 & 11.95 & 12.56 & 12.99 & 13.40 & 14.01 \\
Usu & 3.12 & 5.02 & 6.78 & 8.00 & 9.44 & 10.74 & & & & \\
Muroran & 2.41 & 4.48 & 6.25 & 7.93 & 8.57 & & & & & \\
\hline
\end{tabular}

grow in the sampling station. Transplanted abalones were excluded from these measurements because the growth is remarkably affected by transplantation.

In Shikabe, abalones grow more slowly than in Muroran and Oshamanbe: $7.8 \mathrm{~cm}$ in five years and $9.4 \mathrm{~cm}$ in nine years. In stations between Muroran and Oshamanbe no significant difference in the growth appears until three years of growth. However, some difference appears after four years. Toyoura affords the fastest growth: $11 \mathrm{~cm}$ in five years. In contrast, abalones in Muroran grows to $8.6 \mathrm{~cm}$ in five years, slower than Toyoura by $2.4 \mathrm{~cm}$. Oshamanbe is a favorable place for abalone growth, next only to Toyoura. However, this place provides little growth beyond eight years of life (yearly increase of only 0.15 to $0.25 \mathrm{~cm}$ ). In contrast, abalones in Toyoura continue to grow even after eight years at a rate of 0.41 to $0.61 \mathrm{~cm}$ per year, reaching $14 \mathrm{~cm}$ in 10 years. Abalones grow slowly in Okushiri: difference in growth from other sampling stations amounts to about $1 \mathrm{~cm}$ in two years, and 2 to $5 \mathrm{~cm}$ in five years. The disadvantage of this place finally reaches to 4 to $6 \mathrm{~cm}$ after nine years of growth compared to Toyoura and Oshamanbe.

Compared to other places of Hokkaido (based on the report of Saito ${ }^{11-19)}$ ), growth of Ezo abalone in Funka Bay area are quite satisfactory. Toyoura shows by far the fastest growth in all Hokkaido. Even other places of Funka Bay area are surpassed only by Toi. Based on Sakai's data ${ }^{20)}$ on the grwoth the Ezo abalones in Miyagi perfecture, the following comparison can be made concerning the growth of the second generation abalones in Funka Bay area. Note that comparison of growth among transplanted samples cannot be made because growth are affected by transplantation.) Toyoura and Oshamanbe compare quite favorably with the best places in Miyagi prefecture, whereas the growth in Muroran and Shikabe is one year slower than in unfavorable places of Miyagi.
Relationship between Shell Length and Total Weight

Table 5 shows the dependence of weight of abalone upon shell length, the correlation coefficient, and the weight estimates calculated from the correlation, all being based on samples from the stations except for Abuta and Okushiri.

The correlations of the stations are all considerably high, the highest being 0.987 and the lowest 0.960 . Okushiri is characterized by the lowest calculated weight. Except for this place, other stations showed essentially similar correlations between weight and shell length: 50 to $58 \mathrm{~g}$ for a length of $7 \mathrm{~cm}, 105$ to $114 \mathrm{~g}$ for $9 \mathrm{~cm}$ length, 189 to $194 \mathrm{~g}$ for $11 \mathrm{~cm}$, and 294 to $318 \mathrm{~g}$ for $13 \mathrm{~cm}$. Samples from Okushiri have an average weight of $5 \mathrm{~g}$ when the shell length is $7 \mathrm{~cm}, 15 \mathrm{~g}$ for $9 \mathrm{~cm}$ length and $30 \mathrm{~g}$ for $11 \mathrm{~cm}$.

\section{Relationship among Various Measures of Abalone Shell}

Relations among length, height and width of abalone shells from Toyoura and Okushiri, two representative stations among six places studied, are shown in Fig. 4. Equations derived from these plots are summarized in Table 6 . All three relations can be shown satisfactorily by linear equations with correlation coefficients higher than 0.9 .

No significant difference exists for the length vs. width and width vs. height relations for samples from Toyoura and Okushiri. The length vs. height relations are statistically equivalent but look somewhat different. Compared in terms of shell height and apex height ratio $(\mathrm{A} / \mathrm{H} \times 100)$, both averaged, we detected a significant difference between transplanted and second generation abalones with $99 \%$ probability by the normal distribution analysis.

\section{Abundance of Algae}

Abundances of algae per unit square meter on abalone bed of two representative stations, Koboro district of Toyoura (where abalones grow most rapidly) and Okushiri, are summarized in Table 7. 

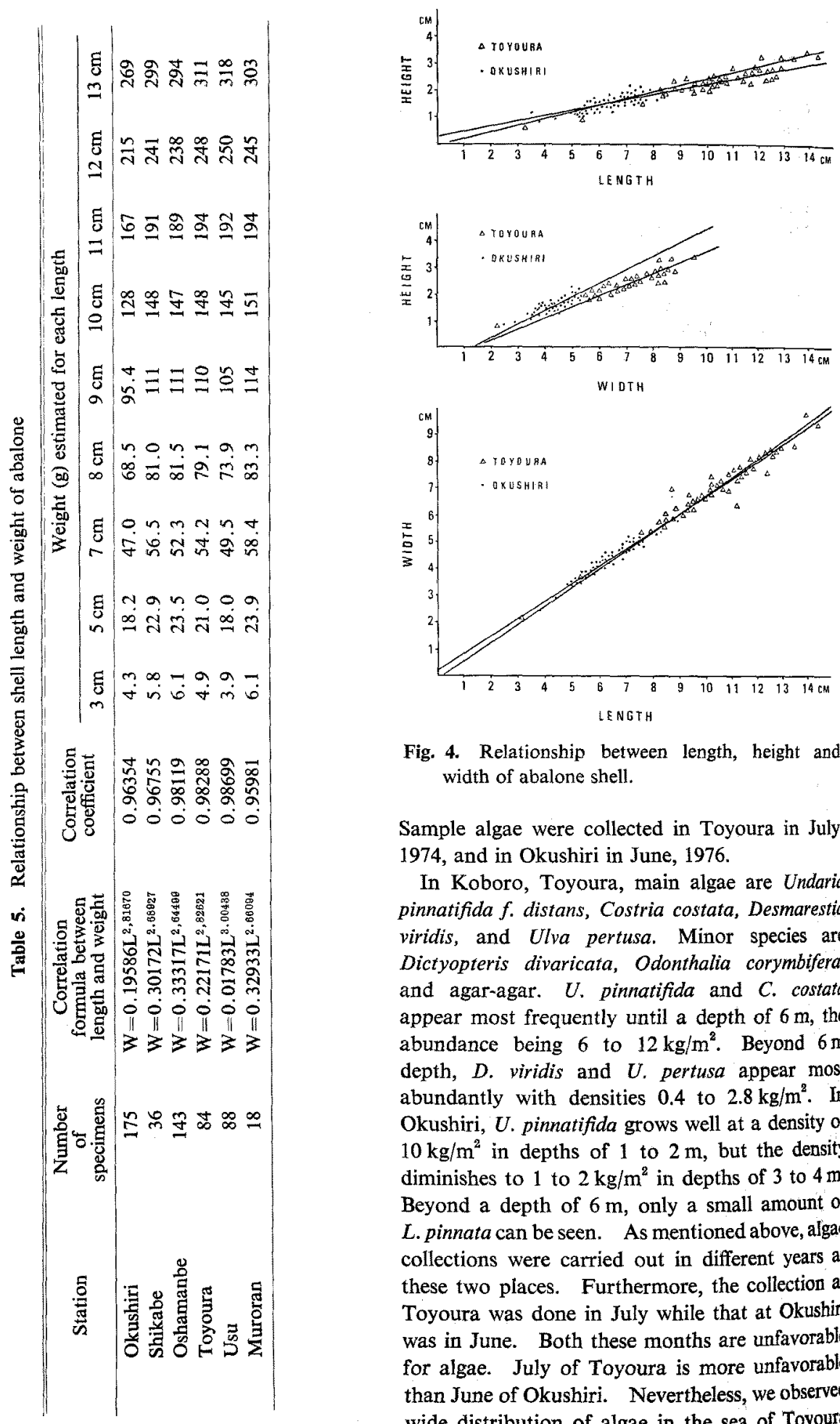

Fig. 4. Relationship between length, height and width of abalone shell.

Sample algae were collected in Toyoura in July, 1974, and in Okushiri in June, 1976.

In Koboro, Toyoura, main algae are Undaria pinnatifida $f$. distans, Costria costata, Desmarestia viridis, and Ulva pertusa. Minor species are Dictyopteris divaricata, Odonthalia corymbifera, and agar-agar. $U$. pinnatifida and $C$. costata appear most frequently until a depth of $6 \mathrm{~m}$, the abundance being 6 to $12 \mathrm{~kg} / \mathrm{m}^{2}$. Beyond $6 \mathrm{~m}$ depth, $D$. viridis and $U$. pertusa appear most abundantly with densities 0.4 to $2.8 \mathrm{~kg} / \mathrm{m}^{2}$. In Okushiri, $U$. pinnatifida grows well at a density of $10 \mathrm{~kg} / \mathrm{m}^{2}$ in depths of 1 to $2 \mathrm{~m}$, but the density diminishes to 1 to $2 \mathrm{~kg} / \mathrm{m}^{2}$ in depths of 3 to $4 \mathrm{~m}$. Beyond a depth of $6 \mathrm{~m}$, only a small amount of $L$. pinnata can be seen. As mentioned above, algae collections were carried out in different years at these two places. Furthermore, the collection at Toyoura was done in July while that at Okushiri was in June. Both these months are unfavorable for algae. July of Toyoura is more unfavorable than June of Okushiri. Nevertheless, we observed wide distribution of algae in the sea of Toyoura 
Table 6. Relationship among shell length, width and height of cultivated Ezo abalone

\begin{tabular}{ccccc}
\hline Relation & Station & $\begin{array}{c}\text { Number of } \\
\text { specimens }\end{array}$ & $\begin{array}{c}\text { Correlation } \\
\text { coefficient (R) }\end{array}$ & Relationship \\
\hline Length-Height & Okushiri & 104 & 0.9428 & $\mathbf{H}=0.2546 \mathbf{L}-0.1060$ \\
& Toyoura & 120 & 0.9026 & $\mathbf{H}=0.2134 \quad \mathbf{L}+0.1490$ \\
Length-Width & Okushiri & 104 & 0.9862 & $\mathrm{~W}=0.6551 \quad \mathrm{~L}+0.2258$ \\
& Toyoura & 120 & 0.9821 & $\mathrm{~W}=0.6496 \quad \mathrm{~L}+0.2506$ \\
Height-Width & Okushiri & 104 & 0.9376 & $\mathbf{H}=0.3811 \mathrm{~W}-0.1647$ \\
& Toyoura & 120 & 0.9092 & $\mathbf{H}=0.3249 \mathrm{~W}+\mathbf{0 . 0 9 1 5}$ \\
\hline
\end{tabular}

Table 7. Distribution of main algae on abalone beds (wet weight $\mathrm{kg} / \mathrm{m}^{2}$ )

\begin{tabular}{|c|c|c|c|c|c|c|c|c|}
\hline Station & Distance from coast line & $0 \mathrm{~m}$ & $25 \mathrm{~m}$ & $50 \mathrm{~m}$ & $75 \mathrm{~m}$ & $100 \mathrm{~m}$ & $125 \mathrm{~m}$ & $150 \mathrm{~m}$ \\
\hline \multirow{7}{*}{ Toyoura } & Depth (m) & 2.0 & 2.8 & 3.9 & 6.0 & 9.0 & 9.7 & 11.2 \\
\hline & Species & & & & & & & \\
\hline & Undaria pinnatifida $f$ distans & 12 & 6 & 8 & & & 8 & 1 \\
\hline & Costria costata & 0.5 & & 2.1 & & 2.4 & & \\
\hline & Desmarestia viridis & & & & 0.4 & 2.8 & & 1 \\
\hline & Ulva pertusa & & & & 0.4 & 0.4 & & 0.4 \\
\hline & Others & 0.8 & & 1.3 & 0.6 & & & \\
\hline \multirow{7}{*}{ Okushiri } & Depth (m) & 2.0 & 2.5 & 3.0 & 4.0 & 5.1 & 6.3 & 7.0 \\
\hline & Species & & & & & & & \\
\hline & Undaria pinnatifida $f$. distans & 1.0 & 1.7 & 1.9 & 0.3 & & & \\
\hline & Colpomenia sinuosa & & 0.3 & & & & & \\
\hline & Scytosiphon lomentaria & 0.3 & 0.2 & & & & & \\
\hline & Desmarestia viridis & 0.2 & & 0.3 & & & & \\
\hline & Laurencia pinnata & & 0.5 & & & 0.4 & & \\
\hline
\end{tabular}

up to a depth of $11 \mathrm{~m}$ or to a distance of $150 \mathrm{~m}$ from coast line. On the other hand, scarcely no algae could be found in the sea of Okushiri beyond a depth of $5 \mathrm{~m}$. Algae distributions are markedly different in both districts especially in depths deeper than $3 \mathrm{~m}$. We conclude that the observed difference in algae distribution is responsible for the significant difference in abalone growth between these two places.

\section{Water Temperature}

Water temperature is one of the obstacles that lead to restricted distribution of Ezo abalone in Hokkaido. Measurements of water temperature were carried out at several places which meet one of the following conditions: (1) places where Ezo abalones have been caught for a long time (Senposshi and Okushiri), (2) places where the occurrence of Ezo abalone has been confirmed after transplantation (Shikabe, Oshamanbe, Usu and Muroran) and (3) places where either the occurrence has never been noticed in spite of the abalone inhabit places in the vicinity, or transplantation of abalone has been attempted in the past but the occurrence thereafter has never been confirmed
(Wakkanai and Urakawa). Coastal water temperatures of these places were measured in 1974 .

Table 8 summarizes the monthly averages of coastal water temperature in the places mentioned above. In Wakkanai and Urakawa where Ezo abalones do not inhabit, the average water temperature in winter, namely from January to March, is below $3^{\circ} \mathrm{C}$. Especially to be noted is the fact that the water temperature in February is close to zero in these places. In contrast, water temperatures in Funka Bay coast are high. The lowest value is higher than $5^{\circ} \mathrm{C}$ even in the January-March period. For eight to nine months from April or May to December, water temperature does not fall below $7^{\circ} \mathrm{C}$. Samani, which locates further east from Urakawa (hence close to the Kuroshio Current), attempted to transplant a total of 25,500 seeds of natural abalone between 1965 and 1968 . Regarding the seeds released in 1968 , a few seeds could be confirmed to exist in autumn of the same year. However, after winter, no piece could be found in 1969. The area of transplantation is inhabited with Mitsuishi tangle (Laminaria angusta) and thus supposed to provide abundant supply of algae. Still, shell lengths were at most $5 \mathrm{~mm}$ and genera- 
Table 8. Average monthly water temperature in Hokkaido (1974)

\begin{tabular}{|c|c|c|c|c|c|c|c|c|c|c|c|c|}
\hline \multirow{2}{*}{ Station } & \multicolumn{12}{|c|}{ Month } \\
\hline & 1 & 2 & 3 & 4 & 5 & 6 & 7 & 8 & 9 & 10 & 11 & 12 \\
\hline Wakkanai & 2.6 & 0.7 & 2.4 & 5.9 & 9.4 & 13.5 & 17.5 & 21.0 & 19.2 & 14.9 & 9.2 & 4.5 \\
\hline Senposhi & 4.1 & 2.9 & 3.1 & 5.7 & 8.4 & 13.7 & 17.8 & 20.9 & 19.0 & 14.3 & 8.7 & 5.6 \\
\hline Okushiri & 6.7 & 5.1 & 5.7 & 8.6 & 11.7 & 15.9 & 20.0 & 23.1 & 20.7 & 16.3 & 11.5 & 8.2 \\
\hline Shikabe & 4.8 & 3.4 & 2.9 & 5.1 & 8.6 & 13.2 & 17.2 & 20.5 & 18.6 & 14.9 & 10.2 & 5.7 \\
\hline Oshamanbe & 5.2 & 5.0 & 4.3 & 6.1 & 7.8 & 14.8 & 17.6 & 21.6 & 18.9 & 15.6 & 9.3 & 6.0 \\
\hline Usu & 4.1 & 3.1 & 4.1 & 8.1 & 11.8 & 16.3 & 21.7 & 23.4 & 22.1 & 16.8 & 11.8 & 7.6 \\
\hline Muroran & 6.5 & 3.8 & 3.8 & 4.0 & 7.8 & 12.4 & 16.6 & 20.0 & 18.9 & 15.3 & 10.2 & 7.0 \\
\hline Urakawa & 2.8 & 0.7 & 1.6 & 3.4 & 6.6 & 10.9 & 16.2 & 19.1 & 19.0 & 14.0 & 8.9 & 5.2 \\
\hline
\end{tabular}

tive cells did not show satisfactory growth. Discouraged by these results, they never attempted the transplantation thereafter in Samani. We interprete this failure as arising from the long period of lower water temperature (below $5^{\circ} \mathrm{C}$ ). On the contrary, according to the studies of Otani and Akiba $^{21}$, the Tsugaru Warm Current and the Kuroshio Current flow alternately within Funka Bay, the switching between these two currents taking place twice a year, namely in the April/May period and the Octobdr/November period. The Tsugaru Warm Current stays within the Bay during winter, namely from November to March, and makes Ezo abalones inhabitable by keeping water temperature higher than on the Hidaka coast. However, the replacement of Tsugaru warm current with the Kuroshio Current in March appears to give some adverse effect to the living of abalones. The survival rate of baby abalone decreases to a minimum in March. We hence believe that the effect of low temperature on the living conditions of abalone works critically also in Funka Bay.

\section{Efficiency of Seed Transplantation}

From 1950 to 1974 , a total of $4,720,000$ Ezo abalone seeds have been transplanted into Funka Bay area (Table 1). The catch for the same period amounted to 288 tons (Table 2). In this area, Toyoura marks the highest points regarding both transplantation and catch. Toyoura keeps complete records of fishing and imposes strict restrictions on the size of abalone that can be caught (shell length $9 \mathrm{~cm}$ ). Fig. 5 shows the relation between the amounts of transplantation and catch based on the data taken by Toyoura township. In accumulated terms, these quantitiescan be correlated each other by a linear equation, $Y=$ $0.1032 X-1.19474(R=0.99465)$. Based on this equation, $X$ is equal to about 120,000 when $Y=0$. (This value of $X$ corresponds to the accumulated

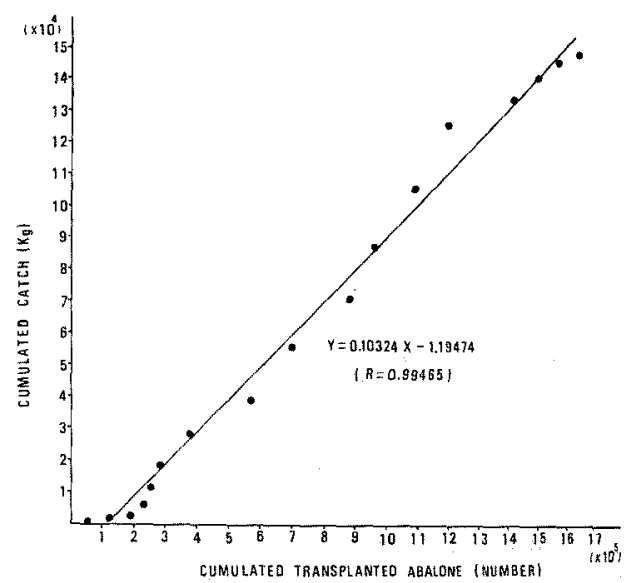

Fig. 5. Relationship between accumulated transplantation and catch of abalone in Toyoura.

transplantation before the first catch). On the northern coast of Funka Bay, abalone fishing starts from the autumn of the year of stocking, as exemplified by Toyoura where the abalone fishing area is located close to the coastal line. However, in Shikabe (the catch is equal to zero), where the fishing area extends to far out in the offing covered mostly with rock plate or rolling stones, fishing of widely distributed stock of 20,000 to 30,000 pieces of abalone is difficult (accumulated transplantation 85,450 seeds). It would be helpful if transplantation is restricted to a smaller area in order to promote the formation of profitable fishing area. Intentional formation of a very large spawning group is a necessary condition from the standpoint of effective reproduction. Various statistics obtained from the present investigation as well as from other sources are summarized in Table 9 . In this Table, the entry $E$ denotes the percentage of finding transplanted abalone found, whereas 
Table 9. Relation between number of transplanted seed and catch of abalone

\begin{tabular}{|c|c|c|c|c|c|c|c|}
\hline & Station & Shikabe & Oshamanbe & Toyoura & Abuta & Usu & Muroran \\
\hline (A) & $\begin{array}{l}\text { Total number of } \\
\text { transplanted seed abalone } \\
\text { from } 1950 \text { to } 1974\end{array}$ & 85,450 & 403,900 & $1,636,727$ & 259,500 & $1,390,000$ & 993,570 \\
\hline (B) & $\begin{array}{l}\text { Total catch from } 1958 \\
\text { to } 1974 \text { (ton) }\end{array}$ & & 34.1 & 148.9 & 10.3 & 71.5 & 22.7 \\
\hline (C) & Sampling date & Oct. 1974 & Aug. '74 & Jun. '74 & Jun. ' 71 & Oct. ${ }^{9} 76$ & Sept. '74 \\
\hline (D) & $\begin{array}{l}\text { Number of collected } \\
\text { specimens }\end{array}$ & 71 & 137 & 250 & 68 & 88 & 18 \\
\hline (E) & $\begin{array}{l}\text { Percentage of finding } \\
\text { of transplanted piece } \\
\text { Calculated number of catch }\end{array}$ & 63.4 & 40.2 & 28.8 & 63.2 & 55.7 & 11.1 \\
\hline (F) & $\begin{array}{l}\text { of abalones (on the as- } \\
\text { sumption that one } \mathrm{kg} \\
\text { contained } 9 \text { shells) }\end{array}$ & & 306,900 & $1,295,100$ & 92,700 & 643,500 & 203,400 \\
\hline (G) & F over A times $100(\%)$ & & 76.0 & 81.9 & 35.7 & 46.3 & 20.5 \\
\hline$(\mathrm{H})$ & $\mathrm{G}$ times $\mathrm{E}(\%)$ & & 30.5 & 23.6 & 22.6 & 25.8 & 2.3 \\
\hline
\end{tabular}

the entry $F$, means calculated number of catch of abalone on the assumption that the average size of landed abalone is $9 \mathrm{~cm}$ in shell length and $105 \mathrm{~g}$ in weight (cf. Table 5). The entry $\mathrm{G}$ denotes percentage of the total calculated catch (entry F) relative to the total number of transplanted seeds. (This entry corresponds to the apparent rate of survival of transplanted seeds on the assumption of zero reproduction). The entry $H$ is obtained by multiplying the apparent survival rate with the probability of finding transplanted piece in the whole specimens (entry E).

Concerning the ratio of the landed number of abalones to the total number of transplanted seeds, $G$, Toyoura, where the highest number of transplantation has been carried out, rate the highest rank $(82 \%)$. Oshamanbe was the second place showing $76 \%$. Usu rated the third with $46 \%$ return, where a large number of seeds, second only to Toyoura, have been transplanted. Then follow Abuta $(36 \%)$ and Muroran $(21 \%)$. In Shikabe $(0 \%)$, no catch has been recorded until now. The return varies greatly from place to place. Especially frustrating is Muroran, where a total of 990,000 seeds have been transplanted since 1950 . This number corresponds to 2.5 times as many as that transplanted to Oshamanbe. However, the calculated total number of catch amounts only to about $2 / 3$ of that of Oshamanbe. As shown clearly in the entry $\mathrm{H}$, the rates of survival of transplanted seeds in the area between Usu and Oshamanbe are at about the same level varying from 23 to $31 \%$. This rate, however, drops sharply in Muroran to about $1 / 10$, or $2.3 \%$. One of the reasons for such a low survival rate at Muroran will be the fact that this place is situated to the eastern limit of inhabitation of Ezo abalone in Hokkaido. The survival rates as high as 25 to $30 \%$ in the area between Usu and Oshamanbe agree with the fact that this area is abundant with algae, one of the most important conditions for the cultivation of Ezo abalone (Table 7). In addition to the fact that the growth rate of this area is also the highest in all Hokkaido (according to Saito ${ }^{11-191}$ ), the abundance of algae appears to be one of the most critical factors to the survival of seed abalones. The seeds grow to commercial size (shell length $9 \mathrm{~cm}$ ) in two years after transplantation. Therefore, a survival level of 25 to $30 \%$ after two years leads effectively to zero or negative profit on yearly basis due to the present, unfavorable balance between the seed price and wholesale price of landed abalone. Nevertheless, if the transplanted abalones lay eggs two times during this period, the secondary generation contributes totally to profit. Hence, the extent of secondary generation as well as the growth rate is of critical importance to the success of transplantation business, as has been pointed out by Kawamura and his coworkers ${ }^{22 !}$. If we simply assume that the rest of transplanted pieces, as can be readily estimated from the entry $E$, is equal to the proportion of the secondary generation, the figure is the highest in Toyoura ( $71 \%$ ), and decreases in the order of Oshamanbe, Usu, and Abuta. (Although Muroran actually gives the highest rate of secondary generation, this station is excluded because of too small number of specimen.) 


\section{Acknowledgement}

The author acknowledges helpful comments and criticism of Dr. Ryogo Yūki, Head of Hokkaido Hakodate Fishery Experimental Station, and assistance of Mr. Satoshi Motoya in the course of this study.

\section{References}

1) M. Yamaguchi: Oyashio, 13, 1-7 (1916).

2) Y. HANDA: Hokkaido (A report of a mission), (1929).

3) DATE TOWN OFFICE: "History of Date-II", San-ichi-shobo, Tokyo, 1972, p. 674.

4) ABUTA TOWN OFFICE: "History of Abuta", Abuta town office, Abuta, 1962, p. 657.

5) T. Kinoshita and S. ShibuYa: Sci. Pap. Hokkaido Fish. Sci. Inst., 1, 2-6 (1949).

6) T. KaWAI, S. NishiKaWA, S. NakAzima, and T. Yoshida: Hokusuishi-geppo, 8(4), 11-14(1951).

7) T. Kawal, S. Nishikawa, S. Nakazima and T, YosHTDA: Hokusuishi-geppo, 10 (5), 14-17 (1953).

8) T. HАYASH: Bull. Hokkaido Reg. Fish. Res, Lab., 12, 1-5 (1955).

9) S. SaKaI: Tohoku Jour. Agri. Res., 11 (3), 239 244 (1960).
10) K. Tomita and K. SAIto: Hokusuishi-geppo, 23 (11), 25-30 (1966).

11) K. SAITo and K. Tommta: Hokusuishi-geppo, 22 (5), 9-25 (1965).

12) K. Saito and K. Kawamura: Hokusuishi-geppo, 23 (2), 22-29 (1966).

13) K. SAITo, S. ToriI, and M. SawasakI: Hokusuishi-geppo, 23 (6), 13-19 (1966).

14) K. SAIto, S. MotoYa, and M. SAWASAKI: Hokusuishi-geppo, 26 (2), 13-23 (1969).

15) K. SAITO: Hokusuishi-geppo, 26 (4), 2-8 (1969).

16) K. SAITo and S. Motoya: Hokusuishi-geppo, 26 (8), 34-44 (1969).

17) K. SArto and S. Motoya: Hokusuishi-geppo, 26 (11), 12-26 (1969).

18) K. Saito, S. Motoya, K. Oono and T. Mishima: Hokusuishi-geppo, 28 (12), 20-36 (1971).

19) K. Sarto, S. Motoya, K. Tomita, K. Tazima, K. Kawamura, T. Mryamoto, J. Taki, N. NishiKaWA, H. Monma, T. IsogaI, S. TAKano, and 0 . IIDA: Hokusuishi-greppo, 31 (8), 1-42 (1974).

20) S. SaKal: Bull. Japan. Soc. Sci. Fish., $28(9)$, 899-904 (1962).

21) K. Ootant and Y. Akiba: Bull. Fac. Fish. Hokkaido Univ., 20 (4), 303-312 (1970).

22) K. Kawamura, T. Hayashi, M. Sato, and M. TaKano: Sci. Rep. Hokkaido Fish. Exp. St., 12, 33-46 (1970). 